\title{
The Return of the Empire: Representations of Race, Ethnicity and Culture in Disney's Tarzan and The Jungle Book, and in the Burroughs and Kipling pre-texts
}

\author{
Helen Thompson
}

\begin{abstract}
There was a child went forth every day. And the first object he look'd upon, that object he became. (Walt Whitman)
\end{abstract}

$\mathrm{R}$ ather than listening to, or reading stories, many children now like to watch them. This reflects the growing popularity of children's films and videos, making this perhaps the most common medium by which many modern children experience the stories deemed as 'classics' within their culture. Once tales were told by one generation to the next, but as the literacy rate increased, this oral tradition was largely replaced by the written text. Now we live in a more technical society where the mass media. particularly its visual images, dominate the socio-cultural domain. With the perception of rampant computer technology taking over, there is a fear that traditional social processes like reading and writing, and even the physical existence of books, will be lost. The fact that children represent a society's future forms the basis for the argument that children should read more, and watch television less. This type of attitude stems from the notion that books are traditionally associated with learning, and film and television with entertainment. One site where entertainment and education often intersect is within the products of the entertainment giant Disney. This phenomenon will be discussed in more detail later, along with the fact that Disney is one of the reasons why many now experience children's 'classics' via the medium of film, as opposed to reading them. The only encounter some children have with certain stories well known in book form by previous generations, such as Snow White. Beauty and the Beast, Aladdin, Tarzan, Winnie the Pooh and The Jungle Book is through their film versions.

One of the main differences between reading a book and watching a film of a particular story is that in the latter case the visual images are supplied rather than imagined, resulting in a limiting of the representations of characters and settings which are available to the viewer. There is also a metonymic function to the way characters are depicted on film, which gives immediate clues to their narrative function. For example in Disney's Aladdin, the image of Jafar, with his hooked nose, bulging eyes and thin lips, immediately signifies evil. He is also depicted as an Arab stereotype, dark skinned and turbanned with a long thin black beard.
In contrast, a read story will be imagined and assigned visual representations in a multitude of diverse ways, according to the individual reader's own system of meaning and values. Although a film's audience has a fixed set of visual images, they are still capable of signifying multiple and diverse meanings, dependent on cultural and ideological viewpoints. The difference is that in a film, the visual representations are already in place. Consequently a written text has more initial range for multiple interpretations according to the reader's discursive positioning, influenced by factors such as socio-economic status, gender, and race, resulting in an opening out of the text's polysemic possibilities at an earlier point than a film version would allow.

Simply put, it is the film-maker who is the 'reader' of the book, and it is the assumptions and imaginative processes of that person that are represented on film, effectively blocking the film viewer from direct access to the original text, as any future or past readings will be tainted by their filmic representations. When a book is adapted to film, a filter is figuratively placed between the audience and the literary pre-text, represented by the socio-cultural values of the film-maker. This is particularly relevant to film adaptations of children's literature, because when children only experience stories that are filtered through a filmmaker's perspective it has a cumulative effect resulting in the perpetuation of certain values, particularly when one production source dominates, as in the case of Disney Studios. Due to Disney's perceived status as the representative of American social norms, and with many critics arguing that this means reinforcement of a predominantly white, middle class, consumerist value system, it is difficult to deny that despite how apolitical the films appear, this value system is pervasively represented, perpetuated by the framework of Disney metanarratives. By metanarrative, I refer to a narrative schema that is constituted by 'the implicit and usually invisible ideologies. systems and assumptions which operate globally in a society to order knowledge and experience' (Stephens and McCallum 1998, p.3). The retelling of stories is a way of passing on a cultural heritage and has the effect of instilling certain value systems as normative.

Disney's animated feature films reinforce particular values 
because the metanarratives that inform them are largely based on North American white, middle class social assumptions. These metanarratives incorporate certain Western ethnocentric assumptions, resulting in the reinforcement of particular ideologies and social values such as individualism, consumerism, class elitism, and masculinism. Perhaps one of the reasons why Disney chooses to re-tell certain classic stories is that the metanarratives of the pre-texts are compatible with Disney metanarratives, even though specific ideologies and dominant discourses may no longer have significance due to their historical contexts. The metanarratives of both the pre-texts and the retellings are part of the 'Western metaethic' and so consequently reinforce Western value systems and cultural heritage. The term 'Western metaethic' was first used by Stephens and McCallum to describe, 'a large interlocked set [of metanarratives], which implies the existence of a less readily definable meta-metanarrative, so to speak, operating at a still more abstract level. This is what determines that a particular narration has value because it offers a patterned and shapely narrative structure, expresses significant and universal human experiences, interlinks 'truth ' and cultural heritage, and rests moral judgments within an ethical dimension' (1998, p.7). They argue that this Western metaethic is what makes certain pre-texts that are already shaped by some kind of metanarrative a good site on which to impose metanarratives expressing social values and attitudes prevailing in the time and place of the retelling (p.6).

For example a metanarrative shaped by the discourses of colonialism and orientalism can be reproduced in retellings that are metanarratively informed by discourses of cultural imperialism. "[The pre-text] functions as a site on which metanarratival and textual processes interact, either to reproduce or contest significance. Because both of these are subject to change between one historical moment and another, any particular retelling becomes, at least potentially, a new negotiation between the already given and the new' (p. 9). The Disney metanarrative has the effect of reinforcing and ultimately presenting North American culture's ideologies and value systems as normative. It is represented by a consistently repeated storyline which can be loosely described as a moral joumey of self-discovery where ultimately good prevails over evil, and usually the morally evolved one also finds true love, and often great wealth and/or power: "Audiences thus learn the roles which pattern their lives, that good always overcomes evil, and that proper behaviour is rewarded, usually by romantic marriage' (Stephens and McCallum in Zipes, 2000, p.161). Disney's The Lion King exemplifies this narrative paradigm which forms part of the afore-mentioned interlocked set of metanarratives referred to as the Western metaethic. In Stephens and McCallum's reading of Disney's The Lion King, the point is made that the pre-destined hero Simba undertakes a moral journey which evokes that of Beowulf and that both these texts draw on The Old Testament myth of Cain. They argue that a modem audience does not need to be familiar with these sources to understand the film's message (1998, p. 106). My examination of certain Disney retellings will also draw on this idea of the Western metaethic to explain why certain narratives seem to express universal experience. Through the prevalence of the Disney product, and its recurring metanarratives that conform to the framework of the Western metaethic, the effect has been the naturalization of certain ideologies and assumptions, arguably providing an archetype that currently makes the Disney version the most emotionally satisfying one for children to watch.

This paper will specifically concentrate on representations of race and ethnicity and their associated cultural forms in certain Disney animated films, particularly in relation to their literary pre-texts. The Disney text becomes multidimensional, mutating into an all encompassing social experience, because of the company's global reach and massive marketing and merchandising programs. Where the original text may have had a limited circulation, the film and subsequent video usually have a much wider multi-national audience, and combined with the Disney film's narrative release in book format, educational products and other associated merchandise, this global saturation has the effect of naturalizing their version as the only version, obliterating the original and creating a Disney 'classic'.

Stories originating in diverse cultures are thus disseminated globally from the central point of Disney's monolithic cultural perspective, and the ideologies that are explicitly or implicitly reinforced and subsequently normalized will 
not be those of the source culture. It is difficult to untangle the Western value system from a Western retelling of a story. According to Stephens and McCallum, 'Because metanarratives are invisible and self-evident and Western audiences assume their metaethic is naturally universal, it is very difficult to resist Westernizing a story at the stages both of production and reception' (1998, p.6). In an attempt to address issues of cultural imperialism, I will here examine what happens when the American Disney corporation retells stories set in India and Africa, as in the case of The Jungle Book (1967) and Tarzan (1999), respectively. If these and other Disney films are perceived as implicated in a colonizing process where a dominant culture speaks for marginalized Others, then perhaps Disney is complicit in perpetuating the discourse of imperialism seen in the original texts, more systemically than even they realize. This time instead of the British Empire the colonizer is the Disney Empire.

For my purposes here, the colonial metanarratives that shaped Rudyard Kipling's The Jungle Book (1894) and Edgar Rice Burroughs' Tarzan of the Apes (1917) will be compared with those of the Disney adaptations in terms of their informing ideologies and how this affects their meaning and significance. I am not interested in comparing adaptations for their artistic merit or according to how accurate they are in relation to the original, but for the ways in which certain ideologies inform the discursive structure of the different versions. It is also useful to compare the different cultural and historical contexts of the two Disney retellings. Vast shifts in social and political attitudes to issues regarding race occurred in the United States between 1967, when Disney made The Jungle Book, and 1999 when Tarzan was released. This interval between 1967 and 1999 encompasses the painful joumey from racial segregation to President Kennedy's 'melting pot' ideal and on to today's concept of multiculturalism, where cultural diversity is recognized and maintained. I will look at how these changes in ideology and practice are reflected in the Disney metanarratives imposed on the retellings, and whether they reinforce or contest those of the pre-texts. This is relevant to the already mentioned notion of how the pluralities of texts and their modes of production can be homogenized into a central unified retelling position and a recognizable metanarrative form, which I feel is exemplified in the Disney animated format. Because the films are directed at children this has important implications in how they view the world as being constructed and consequently for the development of subjectivity.

The original version of The Jungle Book is a discursive partner to Tarzan of the Apes in terms of the assumption that European civilisation is superior to primitive cultures. At first glance, the Disney animated adaptations also appear congruent, in that both films fit into the "born to be a hero' narrative framing. On closer analysis, each film has particular textual and narrative elements that situate the retelling within its own historical and cultural context. As film reviewer Paul Byrnes remarked in regard to a recent Disney animated release Dinosaur, 'This is your usual "orphan boy adopted by a different species who becomes a hero" story - The Jungle Book via Tarzan, but with bigger feet' (2000), illustrating the familiarity of this particular Disney plot formation, and its informing essentialist metanarratives. Both Kipling's The Jungle Book and Burrough's Tarzan of the Apes, through representations of the nature versus culture dichotomy denote and explore the imperial processes of British colonialism. Once again the metaphor for culture (man) is shown as superior to nature. There are obvious parallels with the discourses of colonial rule, man is 'white man' and the apes/wolves represent the 'colonized natives'. Both the pre-texts of Tarzan and The Jungle Book offer the underlying message that man's arrival in the jungle eventually has an ameliorative effect, symbolized when both Tarzan and Mowgli kill the main jungle predators, making life safer for the other animals. This is analogous with the discourse of orientalism: that the natives, or, in Kipling's case, the Indians, are ignorant pagans and are much better off under British colonial rule.

The centrality of certain themes in Disney's animated films reinforce the idea that Westem culture is 'superior', and in a position to speak for and about 'uncivilized' un-Western cultures. In the film adaptations of both The Jungle Book and Tarzan, the prevalent themes are the nature/culture dichotomy, what differentiates humans from animals in terms of gaining subjectivity through agency, and particularly in Tarzan, the theme of romantic love, that ultimately defines and then unites the humans as a similar species. The overriding message is that certain groups are 
culturally privileged and the law of nature determines who belongs to these groups. This deterministic view informs the discourses of colonialism and orientalism and allows for the perpetuation of a modern version of cultural hegemony. These discourses converge and transmute in the Disney retellings, in which the metanarratives that informed European colonial practices, and nowadays those that inform the commercial and cultural global dominance of the United States, find common ground. Where the Disney version contests the metanarrative of the Kipling story is in the message that diversity can be united under one common cultural barrier. Perhaps this is a reflection of American politics around 1967, a period ten years after Brown v. Board of Education put a stop to segregation of the races by law. It was the time of desegregation, then integration, with its accompanying need for busing (Sarat 1997, p.3). Forced integration was imposed from above by the authorities and often resulted in inappropriately high school attendance numbers and hours of travel. What this amounts to is simply a means of perpetuating the power inequities of colonialism. Ultimately, the ideological assumption that enforced racial integration will benefit those previously marginalized, which is also expressed in the Disney film, results in reproducing the significance of the original metanarrative. This is because when one dominant culture, such as Britain (when referring to Burroughs and Kipling), or North America (when referring to the Disney versions of their stories), speaks for and about another culture, it results in that culture being denied its own voice. Therefore Disney in its strategy to unite the world into one homogenous group just ends up perpetuating the ideals of colonialism.

Apart from the imposition of a consistent metanarrative, another defining Disney element, which also occurs in Tarzan, is the ubiquitous popular theme song and catchy musical score, which serves to position the film generically, while functioning as an integral marketing tool, and importantly for my purposes here, the music also operates as a cultural framing device. Indigenous music is used initially to position the contemporary Western viewer as other, but soon the Disney theme song cuts in to claim the story's discursive site. For example the opening music for The Jungle Book uses non-Westem instruments to conjure up images of snake charmers and exotic 'oriental' culture, then suddenly as the camera shot veers away from the animated village (civilization) towards the jungle, the music transforms into a swirling violin piece more suited to a Hollywood drama. This has the effect of defining the focalizing point as a Western one which consequently subordinates the non-white culture to an orientalist representation. In the 1997 mini-feature titled The Making of a Musical Masterpiece that accompanied the re-release on video of Disney's The Jungle Book, it is explained that Walt Disney's first approach to the story was through the music. Originally when he acquired the rights for The Jungle Book in 1962, the Disney animation team designed a film that was true to Kipling's book. The original visual approach was lush and moody with a dark and mysterious song score, and a theme song titled Freedom or Soon We Die. Walt Disney rejected this literal approach to the story and decided to create a film where the characters were based around the music. One song. The Bare Necessities, was retained from the original score and this became the film's centrepiece.

The mini-feature includes current interviews with members of the team who worked alongside Walt Disney on what turned out to be the last production that he personally supervised. One of the movie score's composers proudly notes how Walt preferred his staff to have not read Kipling's original stories. Disney felt the first production team with their dark moody version had been negatively influenced by contact with the Kipling text, so the next team was simply told that it was a story about a kid raised by wolves and then brought back to a man village. In an interesting parallel to Disney's appropriation of his text, Kipling had apparently never visited the remote Seeonee Jungle in India where The Jungle Book is set, but relied on descriptions and photographs supplied by friends (Paffard, 1989, p. 91 ). This equates to the imperial process of imposing cultural dominance on a race of people without understanding their culture, language, or religious beliefs. Said describes the way the young Englishmen who were sent to India to join the civil service had all read the same books, learnt the same lessons, heard the same stories and joined the same clubs on their arrival. Few bothered to learn the native language of the people they ruled with any fluency, even though the native clerks leamt the language of their conquerors (Said, 1993, p.151). 
Disney's method of retelling stories replicates this imperialising process where the flow of knowledge and power is one way only, from the metropolitan centre to the periphery. The pre-text of The Jungle Book was adapted to speak unitarily from Disney's North American culturally dominant focal point in several ways. Thus the original storyline was reduced and altered to give emphasis only to certain characters, and their intersubjective relations. Kipling's The Jungle Book is a collection of stories, not all featuring Mowgli, Bagheera, Baloo or Shere Khan (the enemy tiger), who are the main characters taken up by Disney for its version - according to the opening credits, 'inspired by Rudyard Kipling's Mowgli stories'. As already mentioned, the film is based mainly on personalities and songs, rather than being narrative driven, and this is one of the ways that a predominantly American cultural view is established, evidenced by the dialogue, accents, music and attitudes displayed.

Various intertextual references, that nowadays can also be associated with certain film genres, assist in resituating the text within a Westem cultural heritage. Examples are the scenes of the abandoned baby left in a basket amongst the river rushes, the damsel in distress dropping her water pitcher and needing help, and the seedy New Orleans style jazz club. These images all conspire to reconstitute the story's setting as part of a much broader Western cultural tradition than Kipling's British colonial India. Another factor that conspires to relocate the setting from India to a hybridized Disney (American) space is that Baloo is animated as a North American bear (Murphy in Bell et al 1995, p. 130). The initial focalisation point is also altered in the film, replacing the omniscient third person narrator with Bagheera, the panther, effectively taking ownership of the story. Another means of reshaping the pre-text to be congruent with Disney discourse is by redesignating it generically as a 'buddy' film. The 'buddy' element is common to all the Disney animated films and has the effect of repositioning the text within a Hollywood film tradition, resulting in a reframing of its socio-cultural assumptions. A further contributing factor is the humorous repartee, particularly between Bagheera and Baloo, which is reminiscent of Bob Hope and Bing Crosby in the On the Road films, also providing new generic markers that effectively alter the pre-text's discursive position, and place the retelling squarely within an American cultural framework. Broadly speaking the film can be positioned in a number of film genre categories, obviously as a children's animated film, but it could also fit into the hybrid category of musical-comedy, adventure or road movie. It is this reconfiguring as part of North American cultural heritage that makes the combination of stereotypical narratives with modern Western cultural assumptions seem such a satisfying experience for today's children.

The main animal characters are voiced by established acting, singing and comedic personalities of the time, which has become a staple Disney tool, taking the focus off the narrative and putting it on the characters. In the film the characters speak in a hybridized mix of accents, ranging from upper class British to the American of the deep South. The use of a cultivated British accent to denote an evil character is based on 'a traditional hostility to the aristocratic, elitist, European tradition that so many Americans had originally crossed the ocean ... to get away from' (Hawkins, cited by Stephens and McCallum 1998, p.106). This vocal stereotype marks the character for villainy as evidenced by Scar's accent in The Lion King and Jafar in Aladdin. It is an accent that stands for 'un-American' and therefore evil (ibid, p.106). Shere Khan, The Jungle Book's cunning predatory tiger voiced by George Sanders was an early Disney example of this 'English Nazi' vocal characteristic. Bagheera, the wise and respected panther and the comic figure of the elephant colonel also speak with British accents. Their speech is cadenced differently from Shere Khan's, with the oily 'Vincent Price' quality absent. The Colonel speaks with a stuffy military accent and he even refers to his wife as 'Old Girl', evoking a 'stiff upper lip' style of Britishness.

The colonel and his elephant army patrol the jungle in a fairly ineffectual way, with a lot of pomp and noise, attempting the impossible, to impose order on the jungle. I interpret this as a modern allegory for the passing of British colonial power in India. When the Walt Disney Company, an organization entrenched in a culture defining itself as the leader in world affairs, adapts a story based on British imperial dominance, certain adjustments in representation need to be made, so as to reflect the contemporary world order in political, economic and 
military terms. Although in many ways Disney's Jungle Book attempts to acknowledge its British origins, the story is nevertheless completely taken over by its American retelling. Hence the metanarrative of the pre-text is reproduced and altered at the same time, reinforcing a new set of ideological discourses that have more to do with American cultural dominance than with British colonialism. Walt Disney's main aim was to make the story fun, and the emphasis was on memorable characters, exotic settings, and catchy tunes. It was to be a film based on personalities and songs, and not narrative driven. The narrative was so incidental that the film was designed without an actual ending in place. Finally Walt improvised the 'girl meets boy' and 'boy returns to man village' ending. It is hard to imagine Disney coming up with any other ending. This type of fairy tale conclusion conforms to the European cultural inheritance associated with the Western metaethic, and explains how such an obviously 'tacked' on ending can be so easily integrated into the narrative and accepted by the audience. To me, it appears that Disney has appropriated Kipling's Jungle Book and transformed its colonial discourse into a neo-colonial discourse of cultural imperialism.

Purely from a historicist point of view, the conditions of production of Burroughs' Tarzan of the Apes and Disney's animated film Tarzan are vastly different The pre-text is grounded in a cultural background deeply embedded in the discourses of the British Empire, supporting the institutionalized systems of colonial expansion. On Burroughs' first page the 'British Colonial Office' is imbued with great authority, as the teller of the strange and unbelievable story offers official records from this office to the first person narrator, as proof of his story's veracity. From these office records we leam that a certain young English nobleman, John Clayton, Lord Greystoke, "was commissioned to make a peculiarly delicate investigation of conditions in a British West Coast African Colony from whose simple native inhabitants another European power was known to be recruiting soldiers for its native army, which it used solely for the forcible collection of rubber and ivory from the savage tribes along the Congo and the Aruwimi' (Burroughs 1933, p.6). This one sentence signifies the ideologies that informed the dominant discourse of colonialism which prevailed at the time. The
British were interested in Africa for economic reasons, and felt that their superior management of the natives would be more benevolent than that of the French, even though at the same time they did not want to jeopardize their relations with France. The language is ideologically explicit, referring to the indigenous Africans as 'subjects' and to Britain's colonial ally as a 'European power'. Imperialism and colonialism seem to be entrenched in that era's collective consciousness, as evidenced by the text's casual evoking of some of the attendant cultural assumptions, and in effect naturalizing them as universal truths.

By 1914, European direct colonial dominion had spread to cover eighty five percent of the earth's surface, with the preceding one hundred years of colonial expansion representing the period when the discourse of 'Orientalism' most flourished (Said 1978, p.6). One of the ways that Said defines 'Orientalism' is 'The corporate institution for dealing with the Orient - dealing with it by making statements about it, authorizing views of it, describing it, by teaching it, settling it, ruling over it: in short, Orientalism as a Westem style for dominating, restructuring, and having authority over the Orient' (1978, p.3). The metanarrative of Burroughs' Tarzan of the Apes is based on the discourses of colonialism, imperialism and orientalism, and is congruent with the historical and cultural position of its inception, at the time when Britain and France dominated the Orient and the discourse of Orientalism. Since World War II the United States has dominated the region and according to Said they have approached the Orient in the same way as the French and British colonists did, in that the West is defined as what the Orient is not, and consequently the Orient provides a constant image of Other (1978, p.4). This can be seen in many modern cultural forms that seek to write about the Orient, more often now referred to as the Middle East and Asia, and none more so than in the Disney films which I am looking at.

In Disney's post-colonial adaptation of Tarzan all references to Empire and colonialism are omitted, and the story begins with a shipwreck off a remote and exotic jungle coast 'somewhere' and 'sometime', which in typical Disney fashion, removes all temporal and geographic references. The Disney animated setting is a cultural and historical 
hybrid, where fashion, architecture, and other cultural artifacts are not situated within any recognizable context. This has the effect of nullifying any cultural significance that could be derived from the setting, and allowing the Disney metanarrative to dominate. The film's opening credits are stylized into an orientalist representation of primitive tribal writing, but in English. A primitive tribal drumbeat accompanies the credits, but only briefly, and is soon replaced by the up-tempo beat of a Phil Collin's pop song, designed not for its cultural appropriateness but for mass appeal and Academy Award potential. This theme song has the immediate effect of placing the viewer in a particular discursive site. This space has nothing to do with Africa or the British Empire or even the story of Tarzan, but it has everything to do with inculcating the viewer into the Disney cultural schema. The Phil Collins song provides background for the entire opening sequence, replacing the pre-text's elaborate explanation of British imperial discourse which is exemplified by Burroughs' description of Lord Greystoke: 'Clayton was the type of Englishman that one likes best to associate with the noblest monuments of historic achievement upon a thousand victorious battlefields - a strong virile man - mentally, morally and physically' (Burroughs 1933, p.6). Clayton is portrayed in every way as a superior being, and the novel implies that his offspring Tarzan is endowed with the same physical and mental attributes. Both father and son are born to rule, whether it is over the natives or the apes. Burroughs doesn't draw great distinctions between the two. The notion that certain races are essentially superior and have the right to dominate over inferior races permeates the novel. It is my argument that Disney's adaptations of stories from other cultures perpetuates this process, not in a physical or geographic colonizing sense, but by representing these stories framed within a Western social context, and consequently giving precedence to particularly North American socio-cultural discourses. In The Oxford Companion to Fairy Tales it is argued that 'otherness can be appropriated and transformed into sameness, . . . a charge frequently levelled at the Disney industry, in particular, is that it engages in a neo-colonial co-opting of the folklore and stories of other peoples into the frame of North American society, politics, and capitalism' (Stephens and McCallum in Zipes 2000, p.161).
For a reversion of an existing story to engage with its intended audience, it should in some way be congruent with the dominant social discourses of its contemporary retelling, regardless of whether it supports or subverts them. In Disney's retelling of Tarzan, the discourses of hegemony that inform the metanarrative of Burroughs' text, are replaced by those that support ideologies of diversity and multiculturalism. Instead of Tarzan leaving the jungle to be with his own kind, he achieves subjective agency by staying with the apes and Jane. The Disney version is not completely committed to this idea of ethnic diversity though, as illustrated by the scene where Tarzan removes Jane's glove and matches his hand with hers. This reflects the relief he feels at finding someone like him that he can relate to, unlike his ape family. The metanarratives of the pre-text are aligned with cultural assumptions that promote colonial domination, white male superiority and the privileging of culture over nature, while the metanarratives of the retelling reflect contemporary American values of multiculturalism and the idea that the natural environment is an unspoilt paradise, untainted by civilisation. The change in ideological positions between the two versions is reflective of the historical contexts of their production. According to Stephens and McCallum, 'When new metanarratives are acutely incompatible with the older metanarratives that have shaped a given story, the outcome can be a moment of cultural crisis'. They go on to say that if the new metanarratives "become socially dominant - and hence implicit and invisible - many traditiona! stories will be rendered unreadable and beyond recuperation' (1998, p.9). Even though the site of the pretext has become one of contradiction and contestation, it still remains a site of negotiation because the cultural assumptions that underpin multiculturalism are still being debated in contemporary Western society, meaning that the associated metanarratives are not yet dominant or implicit.

Another reason why the Disney retelling fails to completely negate Burroughs' imperialist metanarrative, is that the Disneyfication process itself effectively colonizes the pretext. The previously mentioned hero paradigm is relevant here also, as Tarzan is predestined to be leader. The ending of Burroughs' novel does not satisfy the European fairy tale narrative pattern in terms of romantic marriage, which 
Disney subscribes to, as Tarzan and Jane do not end up together. Disney changes the ending to conform to most intermediate retellings, particularly those located in popular culture. This metanarrative structure locates the Disney retelling as part of the Western metaethic. Disney's version also alters the text drastically in other ways, so that much of the narrative complexity is omitted, particularly regarding Tarzan's identity as Lord Greystoke. This is reduced to a simple storyline: human baby boy is raised by ape mother after his shipwrecked parents are killed by a leopard. This boy named Tarzan grows up to be more than proficient in the ways of the primates but never really belongs. Eventually other humans come to the jungle and he realizes that he is one of them. Kenneth Kidd (1996) has examined how film often romanticizes the notion of the 'wild child'. Films like Michael Apted's Nell (1994) epitomize the process whereby a person raised in isolation without human language or contact with 'culture' can be miraculously acculturated into the socio-cultural framework in a relatively short amount of time, purely by contact with a kind and patient teacher. Real life studies of this phenomenon suggest otherwise. Kidd gives the examples of Genie, who was raised in severe isolation by elderly parents in Los Angeles, Victor of Aveyron, and the Wolf-girls of Midnapore. These cases all illustrated that much of the acculturation process is gained in childhood, and it is virtually impossible to later reprogram behaviour and responses into what is considered as socially normative.

This theme is central to Disney's Tarzan and The Jungle Book, in that on contact with other humans both Tarzan and Mowgli very quickly embrace human values (romantic love in particular), even though their upbringing has been amongst animals in the jungle. According to Kidd, 'The Jungle Book nonetheless reenacts colonialism, recreating both the myth of the racial other and the child as feral but educable' $(1996$, p.8). This argument also applies to Disney's Tarzan, illustrated by the scenes where Jane shows 'Tarzan slides of 'civilisation', and the implication is that he understands the concept and wishes to go 'there'. Tarzan is rapidly acculturated into the human social system even though his formative years were spent with the apes. He falls in love with Jane and plans to return to England with her, but when the evil white men led by Clayton (transposed from Greystoke aristocrat to unrelated villain) threaten the existence of the apes and the ape leader is killed, he realizes that his place is with the apes as their leader. And then finally the emotionally satisfying romantic Disney ending: even though Jane's character is portrayed as intelligent and strong, she readily conforms to the romance aspect of the Disney metanarrative, by giving up civilization to be with the man she loves. As the final credits roll, Phil Collins musically reasserts that visible and physical differences are merely matters of surface, whereas essentially 'we' re not that different at all'. This song seems to represent the notion of homogenized culture, that even though many races and cultures exist, they can be united under one value system. I think that this is the crux of Disney discourse: no matter what ethnic diversities are being portrayed in the films, the only way the narrative outcomes can be positive for the protagonists is if the metanarrative conforms to the inherent values of the Western metaethic.

Long after the last days of the Raj, Disney has restored India and Africa to Western cultural hegemony by nartating its strangeness, and hence contributing to the Eurocentric practice of positing European (Western) culture as the centre of meaning. According to Robert Stam and Ella Shohat, 'Eurocentrism is the discursive residue or precipitate of colonialism, the process by which the European powers reached positions of economic, military, political and cultural hegemony in much of Asia, Africa and the Americas' (1994, p.297). They point out that Eurocentric practices are still part of contemporary social discourse, '[but] what is new in European colonialism is its planetary reach, its affiliation with institutional power, and its imperative mode, its attempted submission of the world to a single "universal" regime of truth and power' (ibid, p.297). By Europe, they mean neo-Europe, which includes America and Australia. In Disney's retellings of The Jungle Book and Tarzan of the Apes, a kind of cultural hegemony has been achieved through the perpetuation of Orientalist discourses, and also by setting the adaptations in a hybridized cultural space without any temporal referents. The effect is to situate and appropriate the stories as Western (North American).

Once Tarzan and The Jungle Book become part of the 
Disney 'classics' stable, the pre-texts are metaphorically taken over or colonized. This has been achieved by the use of a Western narrative structure and in particular the imposition of the Disney metanarrative on the retellings. Consequently Disney has perpetuated the hegemonic practices that are evident in the way Kipling and Burroughs wrote about India and Africa. Western cultural dominance over the Orient (and much of the rest of the world) is now achieved largely without military force or the need for a physical ruling presence, because non-Westem cultures are to a degree complicit in its implementation. This operates in a similar way to direct colonial relations, as explained by Behdad: 'European power over the Orient must be understood as a productive and dynamic exchange between the two that makes colonial authority tolerable to those on whom it is being imposed. What makes the exercise of colonial power acceptable to the Oriental is precisely the fact that it has a productive function and that it opens positions that meet his or her desires and needs' (ibid, p.12). There is no denying that Said's concept of 'Orientalism' is useful to describe how power imbalances are achieved and maintained in East and West relations, but it is also useful to understand that the processes that are incorporated in orientalism are not fixed, but multiple and dynamic. This can go some way to explain how Disney's appropriation of Oriental culture constitutes an almost contradictory self/other representation, where dominant Western social modes are presented in a stereotypical orientalist context. Disney has taken non-American culture and re-designated it as 'home' by locating its 'strangeness' within familiar Western discourses.

Nowadays empire building works differently. World domination is constituted not in the acquisition of physical territories but through global financial markets. One of the means of doing this is by blurring national boundaries and creating a homogenized 'one world' consumer culture. It is easier for multi-national corporations to produce uniform goods for a homogenized global market, than to produce a diverse range of goods to suit various cultural needs. So global organizations like Disney create markets to suit their products, rather than products to suit their markets. This is the very nature of mass production and mass consumption. Disney's films and associated products offer up a model for subjective formation that is predicated on white, middle-class American consumerism. The construction of consumer identities is a circular and neverending process. Because of this it is important for cultural products like Disney animated films to be discursively interrogated for their informing ideologies. particularly because of their consistent metanarratives and global reach. Mass culture's levelling out of diversity and incorporation of heterogeneity into a unified centre, operates in a similar way to the processes of colonialism.

Marshall McLuhan' s 'global village' is now a fact and not an especially comforting one. CNN has shown us that a supposedly alert, educated population (for instance, the American electorate) can witness the mass destruction of an Arab nation as little more than a spectacular television melodrama, complete with a simple narrative of good triumphing over evil and a rapid erasure from public memory' (Mitchell 1994, p.15). This comment sums up the pervasive and powerful influence that the visual mass media has over their audiences. And because the cultural products that circulate globally are produced and controlled by fewer and fewer sources, the choices for subjective identity are constantly being reduced and homogenized into 'a whole new world' where the values of consumption dominate. Even though the Disney organization itself operates as a unified and monolithic structure, the products that originate from that source function within a network of other representations and discourses from other origins to form a body of knowledge that is held as truth. The discourse of orientalism works in this way, and Disney operates as just part of the uneven matrix that constitutes and perpetuates the notion of Other.

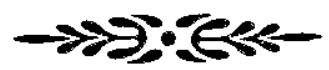

\section{REFERENCES}

Altman, Rick (1999) Film/Genre. London, British

Film Institute.

Behdad, Ali (1994) Belated Travelers. Durham, Duke University Press. 
Bell, Elizabeth; Haas, Linda; Sells, Laura. (eds) (1995) From Mouse to Mermaid. The Politics of Film, Gender and Culture. Bloomington, Indiana University Press.

Burroughs, Edgar Rice (1933) Tarzan of the Apes. London, Methuen.

Byrnes, Paul (2000) Sydney Moming Herald, 15 June.

Fuery, Patrick; Mansfield, Nick (1997) Cultural Studies and the New Humanities. Melboume, Oxford University.

Giroux, Henri (1999) The Mouse That Roared. Disney and the End of Innocence. New York, Rowman and Littlefield.

Goldberg, David Theo (ed) (1994) Multiculturalism. A Critical Reader. Oxford, Blackwell.

Kidd, Kenneth (1996) 'Men Who Run With Wolves, and the Women Who Love Them: Child Study and Compulsory Heterosexuality in Feral Child Films', The Lion and the Unicom 20, 1: 90-112.

Kipling, Rudyard (1994) The Jungle Book. London, David Campbell.

Lowe, Lisa (1991) Critical Terrains: French and British Orientalisms. New York, Cornell University.

Mitchell, W. T. J. (1986) /conology: Image. Text. Ideology. Chicago, University of Chicago Press.

Paffard, Mark (1989) Kipling's Indian Fiction. London, Macmillan.

Prado, C.G. (1995) Starting With Foucault. An Introduction to Genealogy. Boulder, Westview Press.

Said, Edward (1985) Orientalism. Harmondsworth, Penguin.

Said, Edward (1993) Culture and Imperialism. London, Chatto and Windus.

Sammond, Nicholas (1999) 'Manufacturing the American child: child-rearing and the rise of Walt Disney', Continuum: Journal of Media \& Cultural Studies 13:1

Sarat, Austin (ed) (1997) Race, Law, \& Culture: Reflections on Brown v. Board of Education. New York, Oxford University Press.
Smoodin, Eric (1994) Disney Discourse. Producing the Magic Kingdom. New York, Routledge.

Stephens, John (1992) Language and Ideology in Children's Fiction. London, Longman.

Stephens, John; McCallum, Robyn (1998) Retelling Stories. Framing Culture. New York, Garland.

Zipes, Jack, ed. (2000), The Oxford Companion to Fairy Tales. Oxford: Oxford University Press.

Films referred to:

(Both films discussed produced by The Walt

Disney Company)

The Jungle Book (1967) Dir. Wolfgang Reitherman. Tarzan (1999) Dir. Kevin Lima and Chris Buck.

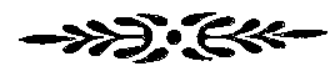

\section{ENDNOTE}

'Disney' will be used throughout to refer to the Walt Disney Company, as distinct from Walt Disney.

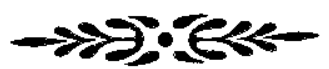

\section{BIOGRAPHICAL NOTE}

In 2001 Helen Thomson graduated from Macquarie University with a BA (Hons) in English. Currently she is working in the Research \& Development Office at the University of Technology, Sydney. Her involvement with children's literature stems in part from looking at the kinds of reading her 8-year-old twin boys choose, and observing how it shapes their view of the world and their place in it. Helen has also developed a particular interest in how cultural and racial identities are formed through literature and, as is evident in her article, she is interested in multi-media adaptations of children's texts and their impact on subjectivity. 